\title{
Expression of Parathyroid Hormone-related Protein in the Rat Glomerulus and Tubule during Recovery from Renal Ischemia
}

Neil E. Soifer, Scott K. Van Why, Michael B. Ganz, Michael Kashgarian, Norman J. Siegel, and Andrew F. Stewart Divisions of Nephrology and Endocrinology, West Haven VA Medical Center, West Haven, Connecticut 06516; Divisions of Nephrology, Endocrinology, Pediatrics, and Pathology, Yale University School of Medicine, New Haven, Connecticut 06510; and Division of Nephrology, The Cleveland VA Medical Center, and Case Western Reserve Medical Center, Cleveland, Ohio 44106

\begin{abstract}
Parathyroid hormone-related protein (PTHrP) is widely expressed in normal adult and fetal tissues, where it acts in an autocrine/paracrine fashion, stimulates growth and differentiation, and shares early response gene characteristics. Since recovery from renal injury is associated with release of local growth factors, we examined the expression and localization of PTHrP in normal and ischemic adult rat kidney. Male SpragueDawley rats underwent complete bilateral renal artery occlusion for $45 \mathrm{~min}$, followed by reperfusion for $15 \mathrm{~min}$, and 2, 6, 24, 48, and $72 \mathrm{~h}$. Renal PTHrP mRNA levels, when compared with sham-operated animals, increased twofold after ischemia, and peaked within $6 \mathrm{~h}$ after reperfusion. PTH receptor, $\beta$-actin, and cyclophilin mRNA levels all decreased after ischemia. PTHrP immunohistochemical staining intensity increased in proximal tubular cells after ischemia, changing its location from diffusely cytoplasmic to subapical by $24 \mathrm{~h}$ after reperfusion. In addition, PTHrP localized to glomerular epithelial cells (visceral and parietal), but not to mesangial cells. PTHrP and PTH stimulated proliferation two- to threefold in cultured mesangial cells. We conclude that PTHrP mRNA and protein production are upregulated after acute renal ischemic injury, that PTHrP is present in glomerulus and in both proximal and distal tubular cells, and that PTHrP stimulates DNA synthesis in mesangial cells. The precise functions of PTHrP in normal and injured kidney remain to be defined. (J. Clin. Invest. 1993. 92:2850-2857.) Key words: parathyroid hormone-related protein • parathyroid hormone - calcium homeostasis • kidney • renal failure
\end{abstract}

\section{Introduction}

Parathyroid hormone-related protein (PTHrP $)^{1}$ is the peptide hormone responsible for most instances of humoral hypercalcemia of malignancy (1-3). While many malignancies overexpress PTHrP, these peptides are also produced by a wide variety of normal tissues, including the central nervous system, pancreatic islets, epidermal keratinocytes, adrenal cortex and medulla, lactating breast, placenta, and vascular smooth muscle (1-3). PTHrP is additionally expressed in the fetus, where it

Address correspondence to Dr. Neil E. Soifer, Research/151C, VA Medical Center, 950 Campbell Avenue, West Haven, CT 06516. 1993.

Received for publication 29 April 1993 and in revised form 2 August

1. Abbreviations used in this paper: MC, mesangial cell; PTHrP, parathyroid hormone-related protein.

The Journal of Clinical Investigation, Inc.

Volume 92, December 1993, 2850-2857 is present in virtually every organ system and is believed to be essential for normal growth and development (1-4). PTHrP is believed to act in an autocrine and/or paracrine fashion in these tissues, although its exact biological function has not been clearly established. Its extraordinarily wide tissue distribution, its highly conserved amino acid sequence (1-3), and the observation that "knockout" of the PTHrP gene in transgenic mice is lethal (5) collectively suggest that PTHrP has important physiological roles.

In addition, PTHrP has been detected in both adult and fetal kidney. In kidney sections from the human and rat fetus, PTHrP has been identified histochemically in glomerulus and tubules (proximal, distal, collecting tubule) until mid to late gestation, at which time glomerular staining disappears while tubular staining remains (6-8). Northern blot analysis has shown PTHrP mRNA present in human kidney as early as 10 wk of gestation (6), and PTHrP immunoreactivity has been reported in acid-urea extracts of adult kidney (9). The precise physiological role of PTHrP in the kidney is not clear, although it has been shown to potentiate growth in cultured madindarby canine kidney distal renal tubular cells (10) and in cultured human renal carcinoma cells (11). PTHrP has also been shown to have TGF- $\beta$-like effects (12) and to share characteristics with the early response gene family $(13,14)$. To date, no study has addressed the localization or functional role of PTHrP in normal renal physiology or in tubular or glomerular disease. Since renal injury and subsequent recovery are associated with the enhanced expression and action of a number of other cytokines and growth factors, since PTHrP is expressed during renal development, and since PTHrP has been credited with growth factor-like activity in a number of tissues, including the kidney, we have explored the expression, localization, and action of PTHrP in a well-characterized model of renal ischemia, acute tubular necrosis, and eventual recovery.

\section{Methods}

Renal ischemia model. This model has been described in detail previously (15), and has been approved by the Yale Animal Use Committee. Male Sprague-Dawley rats weighing 225-300 g were used for all experiments and were allowed free access to water and standard rat chow before anesthesia. Animals undergoing renal ischemia were anesthetized with pentobarbital sodium ( $50 \mathrm{mg} / \mathrm{kg}$ i.p.) or thiobutabarbital sodium (Inectin; $80 \mathrm{mg} / \mathrm{kg}$ i.p.), placed on a warming board, and maintained at $36.5-37.5^{\circ} \mathrm{C}$. After catheterization of the external jugular vein, the kidneys were exposed through an abdominal incision, and the aorta and right renal artery dissected free from surrounding tissue. Animals were then heparinized ( $500 \mathrm{U} / \mathrm{kg}$ i.v.) for $10 \mathrm{~min}$. Bilateral renal ischemia was then induced with a vascular clamp placed across the aorta just proximal to the left renal artery and with a Silastic sling looped around the right renal artery. Clamps were removed after $\mathbf{4 5}$ min of complete renal artery occlusion, and uniform reperfusion of the kidneys was visually confirmed. Isotonic saline was administered to 
replace surgical fluid loss ( $2 \%$ body weight), and maintenance fluids of $1.2 \mathrm{ml} / \mathrm{h}$ were infused for recovery periods of $>15 \mathrm{~min}$, with free access to water for those animals with recovery periods of at least $24 \mathrm{~h}$. Kidneys were reperfused for $15 \mathrm{~min}$, and 2, 6, 24, 48, and $72 \mathrm{~h}$. Animals were killed at each of these reflow time points; both kidneys were then harvested, immediately frozen in liquid nitrogen, and stored at $-70^{\circ} \mathrm{C}$ until RNA extraction was performed. Sham-operated animals underwent identical procedures with the exception of renal artery occlusion. Kidneys were harvested from sham-operated animals at times equivalent to the 2- and 6-h reflow periods.

Kidney RNA extraction, Northern blot analysis, and RNase protection assay. Frozen tissue $(0.3-0.5 \mathrm{~g})$ was homogenized with a Tissuemizer (Tekmar) in $4 \mathrm{M}$ guanidine isothiocyanate and $0.1 \mathrm{M}$ 2-mercaptoethanol. Total RNA was extracted from whole rat kidney at each reflow time point using the guanidine isothiocyanate/guanidine hydrochloride variation of the methods of Chirgwin et al. (16) and of Chomczynski and Sacchi (17). For Northern blot analysis, $20 \mu \mathrm{g}$ of total RNA was analyzed on $1 \%$ agarose/formaldehyde gels, then transferred onto nylon-supported nitrocellulose filters and fixed at $80^{\circ} \mathrm{C}$ for $1 \mathrm{~h}$. Prehybridization was performed for $2-4 \mathrm{~h}$ at $42^{\circ} \mathrm{C}$ in a $50 \%$ formamide solution containing $6.6 \times \operatorname{SSC}(1 \mathrm{M} \mathrm{NaCl}, 0.1 \mathrm{M} \mathrm{Na}$ Citrate $)$, $0.1 \%$ SDS, $5 \times$ Denhardt's $(0.1 \%$ Ficoll, $0.1 \%$ polyvinyl pyrrolidone, $0.1 \%$ BSA ), $0.01 \mathrm{M}$ EDTA, and $200 \mu \mathrm{g} / \mathrm{ml}$ of denatured salmon sperm DNA. Filters were hybridized overnight under the same conditions using a random-primed rat PTH/PTHrP receptor cDNA probe encompassing the first 2,100 nucleotides of the coding region, generously provided by Drs. H. Jüeppner, A-B Abou-Samra, and G. V. Segre (18). After hybridization, filters were washed as indicated in the legend to Fig. 3, then analyzed by autoradiography. Filters were stripped by washing at $65^{\circ} \mathrm{C}$ in a solution of $15 \mathrm{ml}$ formamide, $3 \mathrm{ml} 0.1 \times \mathrm{SSC} / 1 \%$ SDS, and $12 \mathrm{ml}$ DEPC-treated water, and were rehybridized under similar conditions to actin and cyclophilin probes. Differences in RNA loading were analyzed by hybridizing the filters with an oligonucleotide probe to the $28 \mathrm{~S}$ subunit of ribosomal RNA. All conditions for prehybridization, probe labeling, hybridization, and filter washing were performed as described by Barbu and Dautry (19).

Ribonuclease (RNase) protection assays were performed as described (20) using $20 \mu \mathrm{g}$ of total RNA and a 343-bp PvulI-Bgl II antisense probe corresponding to the coding region of the rat PTHrP cDNA. An antisense cyclophilin probe was added to each sample to provide an internal standard using a 230-bp Sam3A-BamHI fragment of the rat cyclophilin cDNA (20) subcloned into pGEM blue vector (Promega Biotec, Madison, WI). Protected fragments were fractionated on a $5 \%$ polyacrylamide $/ 7 \mathrm{M}$ urea sequencing gel and analyzed by autoradiography.

Immunofluorescence. In a different set of animals exposed to renal ischemia and reflow, ischemic rat kidneys were fixed in situ by intraarterial infusion of paraformaldehyde-lysine-sodium periodate into the aorta distal to the origin of both renal arteries. Kidneys were removed, exposed to fixative for an additional $1 \mathrm{~h}$ at room temperature, and then sliced into 1-mm-thick sections. These slices were washed three times in PBS, equilibrated in 10\% DMSO for $10 \mathrm{~min}$, then frozen in freon 22 supercooled by liquid nitrogen. Tissue was stored in liquid nitrogen without thawing until sectioned with a cryostat at $4 \mu \mathrm{m}$. Before staining, frozen sections were quenched with $50 \mathrm{mM} \mathrm{NH}_{4} \mathrm{Cl}$, and nonspecific staining was blocked with $1 \%$ BSA in PBS. Affinity-purified rabbit antibodies to PTHrP regions $1-36$ or $37-74(21,22)$ were then added in the presence of BSA and protease inhibitors (aprotinin, $500 \mathrm{KIU} /$ $\mathrm{ml}$; leupeptin, $5 \mu \mathrm{g} / \mathrm{ml}$; pepstatin, $5 \mu \mathrm{g} / \mathrm{ml}$; EDTA, $1 \mathrm{mM}$ ) for $2 \mathrm{~h}$ at room temperature, followed by six 5-min washes with PBS, $1 \%$ BSA, protease inhibitors. Sections were then exposed to anti-rabbit fluorescein isothiocyanate-conjugated goat $\mathrm{F}\left(\mathrm{ab}^{\prime}\right)_{2}$ fragments (Tago Immunologicals, Burlingame, $C A$ ) in a 1:200 dilution for $30 \mathrm{~min}$ in a darkened moisture chamber. Indirect immunofluorescence was subsequently examined using an Axiophot fluorescent microscope (Carl Zeiss, Inc., Thornwood, NY). For more detailed analysis, confocal microscopy was performed with an MRC-600 scanning laser microscope (Bio-Rad Laboratories, Richmond, CA) using a predetermined aperture size for an acceptable signal-to-noise ratio, and with the same objective lens (water immersion, $\times 50$ numeric aperture 1.0 , E. Leitz Inc., Wetzlar, Germany) and neutral density filter setting for all samples.

Mesangial cell (MC) isolation and culture. MCs were isolated and cultured from perfused kidneys obtained from young male rats by previously described procedures (23). For these experiments we used subcultures of the second to eighth passages of MCs grown at $37^{\circ} \mathrm{C}$ in $5 \%$ $\mathrm{CO}_{2}$ and $95 \%$ air. The identity of the MCs was established by several criteria. Morphologic evaluation of MC cultures revealed a homogeneous population of stellate or fusiform cells with prominent intracellular fibrillar structures. These morphologic features of cultured MCs have been described previously (24). In addition, we used indirect immunocytochemistry with both rabbit IgG antibodies directed against vascular smooth muscle myosin and fluorescein isothiocyanate-conjugated mouse IgG antibodies directed to IgG and Thy-1.1. These studies showed uniformly strong positive staining of distinct longitudinal fibrils in all observed cells. This staining pattern of glomerular cell outgrowth is considered to be indicative of $\operatorname{MCs}(24,25)$. Subcultured MCs were grown in $75-\mathrm{cm}^{2}$ flasks in Dulbecco's minimum essential medium that contained $10 \% \mathrm{FCS}, 5 \mu \mathrm{g} / \mathrm{ml}$ insulin, $10 \mathrm{mM}$ L-glutamine, $400 \mathrm{ng} / \mathrm{ml}$ penicillin, $500 \mathrm{ng} / \mathrm{ml}$ streptomycin, and $25 \mathrm{mM} \mathrm{HCO}_{3}$.

$M C$ proliferation assay. For cell proliferation studies, MCs were subcultured in 96 -well plates at a density of $10^{3}$ cells/well. The cells were washed in a saline solution twice before being incubated in serumfree, $0.1 \% \mathrm{BSA}, 5 \mu \mathrm{g} / \mathrm{ml}$ insulin, $\mathrm{HCO}_{3}$-containing medium buffered at pH 7.4 for 48 h. PTHrP (1-36) and bPTH (1-34), $7 \times 10^{-9} \mathrm{M}$ each, were added as a $20 \mu$ l volume to each well to obtain the desired concentration. $\left[{ }^{3} \mathrm{H}\right]$ Thymidine was added at $0.5 \mu \mathrm{Ci} /$ well $24 \mathrm{~h}$ before harvesting, which was performed at 24,48 , or $72 \mathrm{~h}$ after addition of agonist. Control wells received only the appropriate vehicle solution. Replication of DNA and MCs was determined by counting $\left[{ }^{3} \mathrm{H}\right]$ thymidine incorporation into DNA. Harvesting of MCs entailed detaching MCs from the plate using a 1:10 dilution of trypsin/EGTA solution followed by collection of all $\left[{ }^{3} \mathrm{H}\right]$ thymidine-incorporated DNA on glass fiber strips using an automated cell harvester (Cambridge Technology, Cambridge, MA). $\left[{ }^{3} \mathrm{H}\right]$ Thymidine content was counted in a beta scintillation counter (Beckman Instrs., Inc., Fullerton, CA) at $5 \mathrm{~min} / \mathrm{sam}$ ple. To determine MC proliferation by cell count, cells were washed and then incubated in a 40- $\mu$ l mixture of trypsin, collagenase, deoxyribonuclease, and $0.1 \%$ EGTA for $1 \mathrm{~h}$ at $37^{\circ} \mathrm{C}$. The detached MCs were resuspended in an equal volume of $0.4 \%$ Trypan blue and the number of viable cells were counted in a counting chamber.

\section{Results}

PTHrP $m$ RNA in sham-operated and ischemic kidney. Steadystate PTHrP mRNA levels in the rat kidney and after $45 \mathrm{~min}$ of bilateral renal ischemia as assessed by RNase protection assay are shown in Fig. 1. In the sham-operated animals, PTHrP mRNA was near the limit of detection. In the ischemic kidneys, however, PTHrP mRNA levels began to increase by $2 \mathrm{~h}$ after reperfusion, and peaked within $6 \mathrm{~h}$ before returning to baseline levels by $48 \mathrm{~h}$ after ischemia. By comparison, cyclophilin mRNA levels decreased after ischemia, reaching a nadir within 2-6 h of reperfusion and returning to baseline by $48 \mathrm{~h}$ after injury (Fig. 1). Densitometric analysis of the PTHrP measurements (Fig. 2) shows a consistent increase in PTHrP mRNA levels by a mean of twofold over sham-operated animals within $6 \mathrm{~h}$ after injury and reperfusion. The densitometry results combine observations from four RNase protection assays in six sets of kidneys.

$P T H$ receptor $m R N A$ in sham-operated and ischemic kidney. PTHrP binds to and acts through the classical PTH receptor in the kidney (1-3). Since ischemia causes an increase in 


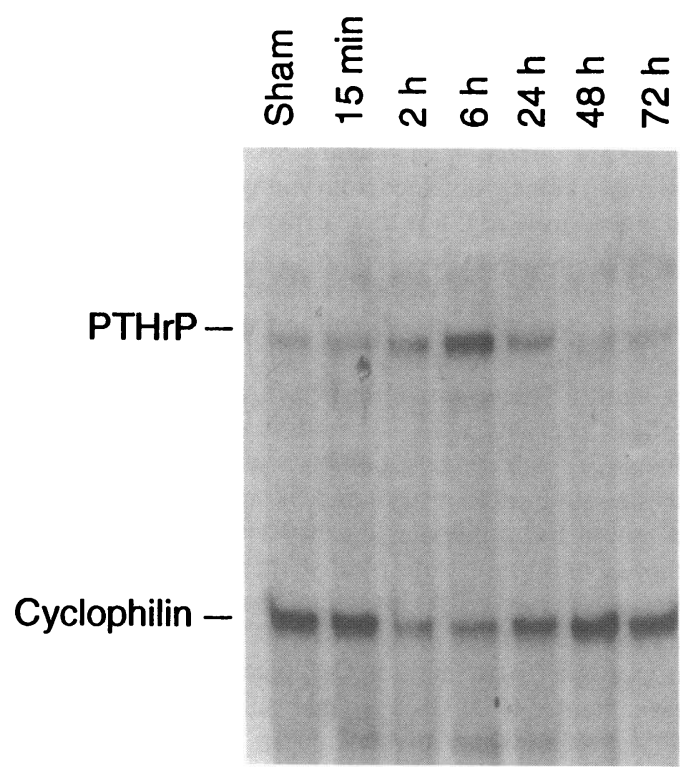

Figure 1. RNase protection analysis of PTHrP mRNA levels after ischemic injury. Each lane represents $20 \mu \mathrm{g}$ of total RNA prepared from whole rat kidney derived from sham-operated animals and from each of the indicated reflow time points after ischemia. The upper bands correspond to PTHrP mRNA; the lower bands correspond to cyclophilin mRNA (loading standard). Note that PTHrP mRNA expression peaks at $6 \mathrm{~h}$ after reperfusion in this experiment.

PTHrP mRNA levels, we questioned whether this would result in changes in the level of PTH receptor mRNA expression in the rat kidney. As seen in Fig. $3 A$, PTH receptor mRNA levels decreased within the first $2 \mathrm{~h}$ after reperfusion. By $72 \mathrm{~h}$ the PTH receptor mRNA levels had not returned to baseline.

To document that the decrease in PTH receptor mRNA was not a result of sample loading differences, the filter was

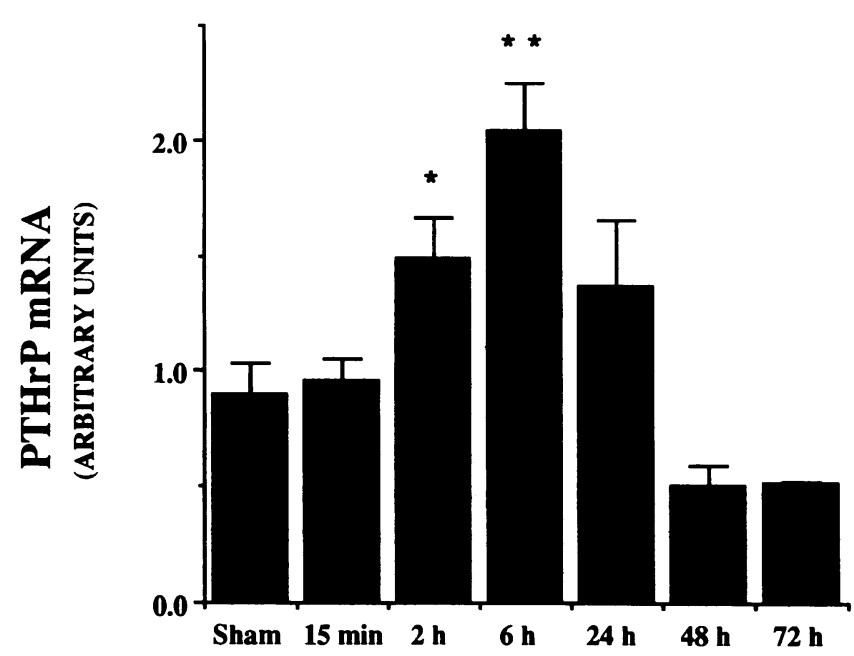

Figure 2. Densitometric analysis of PTHrP mRNA levels after renal ischemia as determined in multiple experiments analogous to those shown in Fig. 1. Bars indicate the ratio of PTHrP mRNA to cyclophilin mRNA as assessed using densitometry after RNase protection analysis. Each bar represents the mean value of mRNA prepared from six kidneys for the sham, 15-min, and 2-, 6-, and 24-h time points, and from two kidneys for the remaining two time points. ${ }^{*} P=0.025$; $* * P=0.004$ reprobed for $\beta$-actin and cyclophilin. As seen in Fig. 3, $B$ and $C$, both $\beta$-actin and cyclophilin mRNA levels also decreased after ischemic injury, reaching nadirs between 2 and $6 \mathrm{~h}$ after reperfusion. When the same filter was probed for $28 \mathrm{~S}$ ribosomal RNA (Fig. $3 \mathrm{D}$ ), relatively minor differences in the amount of 28S RNA were observed on the filter at the different time points. Thus, only a portion of the fall in PTH receptor mRNA could be accounted for by loading differences or RNA degradation. These considerations make the increment in PTHrP mRNA shown in Figs. 1 and 2 more striking.

Immunohistochemical localization of PTHrP. Since PTHrP mRNA was found to be present in RNA prepared from whole normal rat kidney and its production stimulated by ischemic injury, and since the location of PTHrP in the adult rat kidney is unknown, we attempted to localize the source of PTHrP in the rat kidney. Immunohistochemistry was performed on frozen sections of PLP-fixed sham-operated and ischemic kidneys using region-specific, affinity-purified anti-

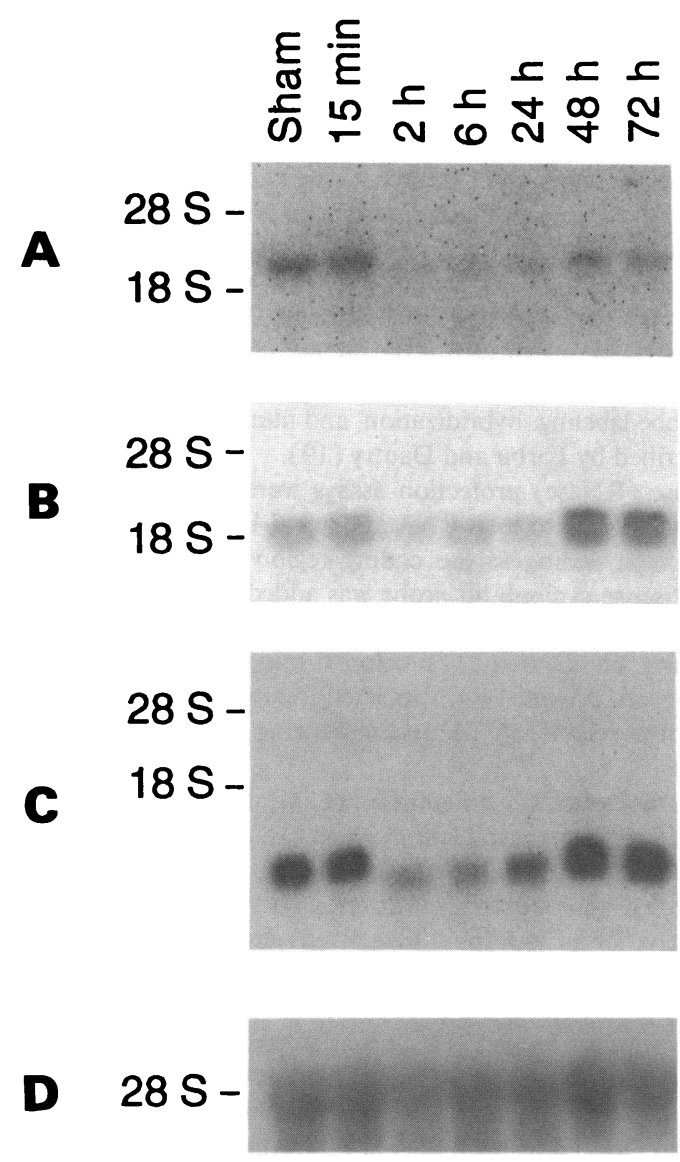

Figure 3. Northern blot analysis of total RNA from whole rat kidney after ischemic injury. $(A)$ Hybridization with a random-primed rat $\mathrm{PTH} / \mathrm{PTHrP}$ receptor cDNA probe in sham-operated animals and at each reflow time point. $(B)$ Hybridization with a labeled $\beta$-actin probe. $(C)$ Hybridization with a labeled rat cyclophilin probe. $(D)$ Hybridization with a labeled $28 \mathrm{~S}$ ribosomal RNA probe. The same filter was used for each hybridization, and $20 \mu \mathrm{g}$ of total RNA was loaded into each lane. Wash conditions: $0.1 \times$ SSC, $0.1 \%$ SDS for 60 min at $65^{\circ} \mathrm{C}(A) ; 1 \times \mathrm{SSC}, 0.1 \% \mathrm{SDS}$ at $42^{\circ} \mathrm{C}$ for $30 \mathrm{~min}$, then $50^{\circ} \mathrm{C}$ for $30 \mathrm{~min}(B$ and $C) ; 2 \times$ SSPE, $0.1 \%$ SDS, $0.1 \%$ Na pyrophosphate for $10 \mathrm{~min}$ at $42^{\circ} \mathrm{C}(D)$. Note that steady-state PTH/PTHrP receptor, $\beta$-actin, and cyclophilin mRNA levels all fall at 2-6 $\mathrm{h}$ after reperfusion. 
bodies to PTHrP regions $1-36$ and 37-74. As seen in Fig. $4 \mathrm{~A}$, addition of anti-PTHrP (37-74) antibody to sections from sham-operated animals reveals prominent glomerular staining. The glomerular staining is confined to epithelial cells, both visceral and parietal, without mesangial cell or endothelial cell staining (Fig. 4, $A$ and $B$ ). A similar glomerular pattern was observed using anti-PTHrP (1-36) antibody. The intensity and pattern of glomerular staining was corroborated by confocal microscopy (Fig. $4 \mathrm{C}$ ) and did not change appreciably after ischemic injury. Preincubation with excess PTHrP (37-74) or
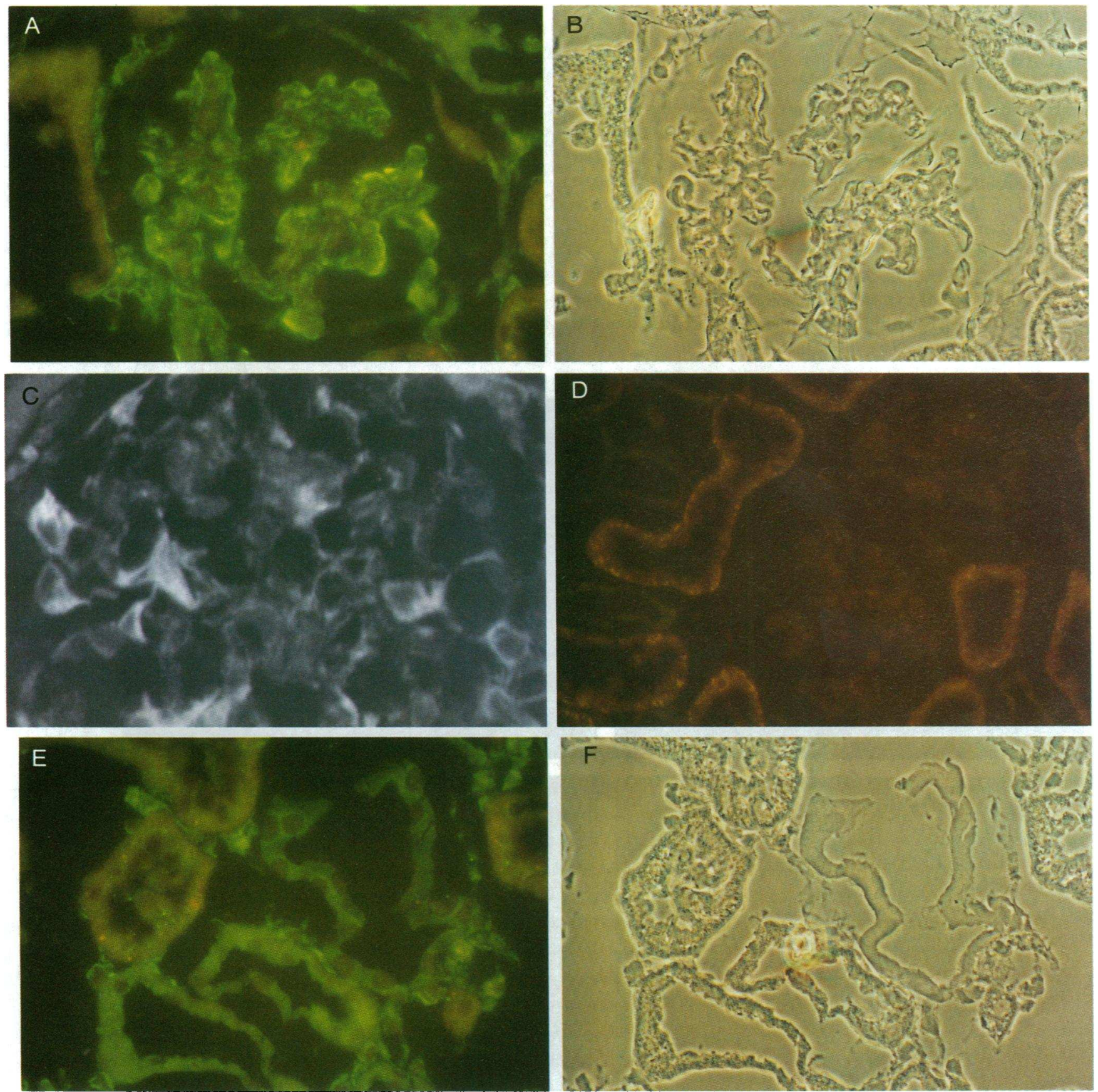

Figure 4. Immunohistochemical localization of PTHrP in rat kidney. All staining was performed on frozen sections of PLP-fixed tissue using affinity-purified, region-specific antibodies. Kidney sections shown represent staining with an anti-PTHrP (37-74) antibody. A similar pattern was observed with addition of an anti-PTHrP (1-36) antibody (not shown). $(A)$ Glomerulus from sham-operated animal stained with antiPTHrP (37-74) antibody $(\times 630)$. (B) Phase-contrast exposure from glomerulus shown in $A(\times 630)$. (C) Confocal microscopy of glomerular staining in sham-operated animals $(\times 900)$. (D) Glomerulus from sham-operated animal stained with anti-PTHrP (37-74) antibody preincubated with $10^{-6} \mathrm{M}$ PTHrP $(37-74)(\times 400)$. (E) Tubules from sham-operated animals stained with anti-PTHrP $(37-74)$ antibody $(\times 630)$. $(F)$ Phase-contrast exposure from tubules shown in $E(\times 630)$. 
(1-36) peptides $\left(10^{-6} \mathrm{M}\right)$ eliminated the glomerular epithelial cell staining (Fig. $4 \mathrm{D}$ ).

PTHrP was also found to be present in both proximal and distal tubular cells when examined by conventional fluorescent microscopy (Fig. 4, $E$ and $F$ ). In contrast to the glomerular epithelial cell staining, however, the tubular pattern of fluorescence was altered after ischemia (Fig. 5). In sham-operated animals, proximal tubular localization of PTHrP by confocal microscopy was primarily in a vesicular pattern within the cytoplasm (Fig. $5 \mathrm{~B}$ ). After $6 \mathrm{~h}$ of reperfusion, the intensity of PTHrP staining was increased and was now present in a diffuse cytoplasmic distribution (Fig. $5 \mathrm{C}$ ). By $24 \mathrm{~h}$ after ischemic injury, the diffuse cytoplasmic staining remained, but an additional vesicular staining pattern was present in a subapical location (Fig. $5 \mathrm{D}$ ). As with glomerular staining, this tubular staining disappeared when antibody was incubated with excess $\left(10^{-6} \mathrm{M}\right)$ PTHrP (37-74) peptide. Identical tubular and glomerular staining patterns were seen with addition of antiPTHrP (1-36) antibody (not shown).

Cellular proliferation. Since MCs are stimulated to proliferate by a number of cytokines and hormones, and given the presence of PTHrP within the glomerulus, the question was raised as to whether PTHrP (1-36) would also act as a mitogen in mesangial cells. These results are shown in Fig. 6. PTHrP (1-36) at $7 \times 10^{-9} \mathrm{M}$ stimulated a two- to threefold increase in $\left[{ }^{3} \mathrm{H}\right]$ thymidine incorporation in cultured MCs. MCs exposed to $7 \times 10^{-9} \mathrm{M}$ bPTH (1-34) showed a similar response. These findings were confirmed using direct cell counting of MC numbers from parallel experiments, as indicated in the legend to Fig. 6.

\section{Discussion}

The recovery phase of acute renal failure has recently become an area of considerable interest. Much investigation has focused on the regenerative phase in renal tubular cells, and on the changes in gene expression that result in increased production of local cytokines and growth factors that contribute to the regenerative process $(26,27)$. For example, the renal synthesis of EGF and IGF-I is altered after ischemic injury, and administration of these agents just before or during ischemia results in an enhanced renal tubular proliferative response, a lower peak blood urea nitrogen and serum creatinine, and a more rapid return to normal renal function compared with untreated ani-
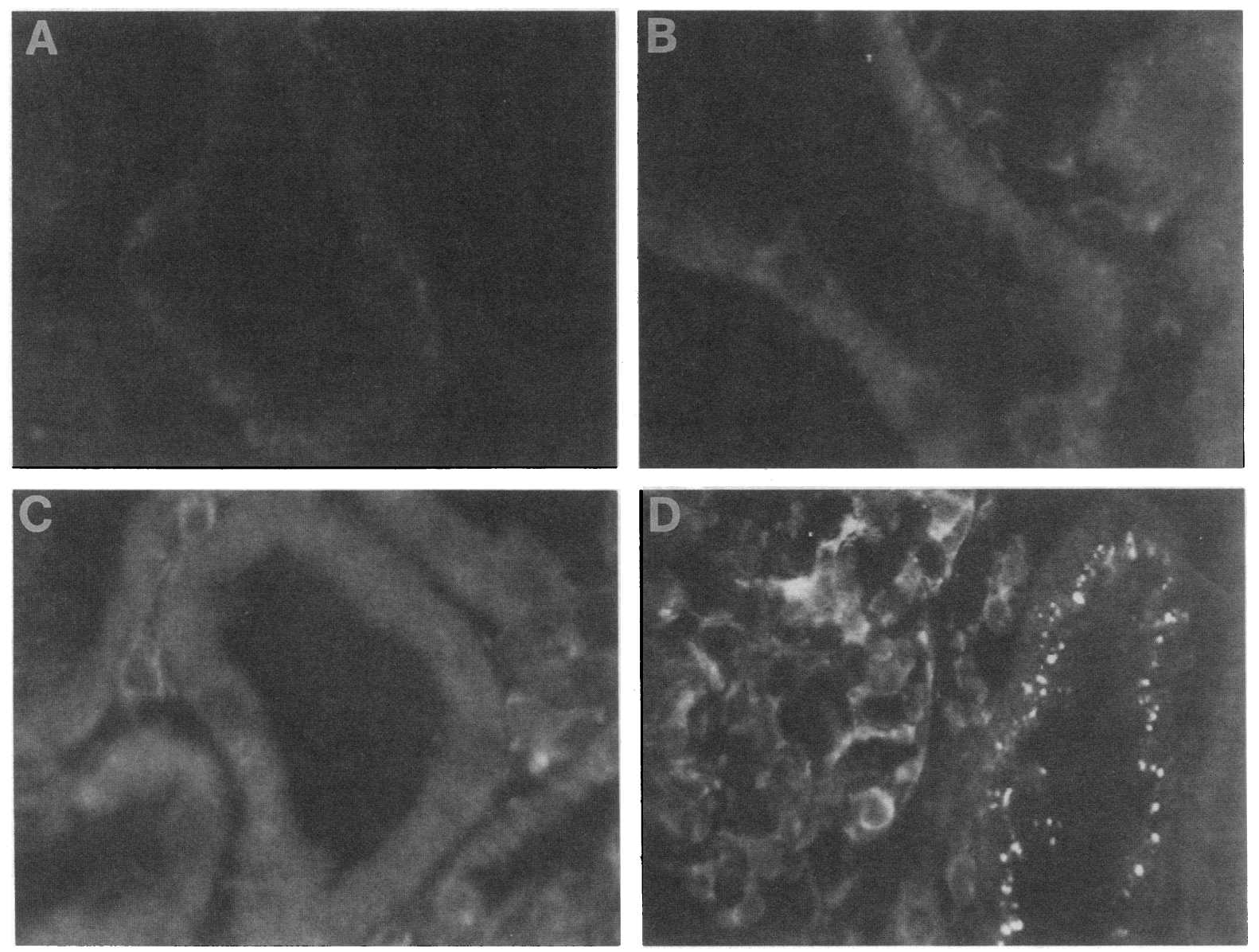

Figure 5. Immunofluorescent localization of PTHrP in proximal tubule by confocal microscopy. Fluorescent labeling was performed on PLPfixed frozen tissue sections from sham-operated and ischemic rat kidney using affinity-purified, anti-PTHrP (37-74) antibody. $(A)$ Normal proximal tubule without addition of primary antibody. $(B)$ PTHrP in proximal tubule of sham-operated rat kidney. $(C)$ PTHrP in proximal tubule of ischemic kidney after $6 \mathrm{~h}$ of reperfusion. $(D) \mathrm{PTHrP}$ in proximal tubule of ischemic kidney after $24 \mathrm{~h}$ of reperfusion. Staining with affinity-purified anti-PTHrP (1-36) antibody produced a similar staining pattern. $\times 900$. 


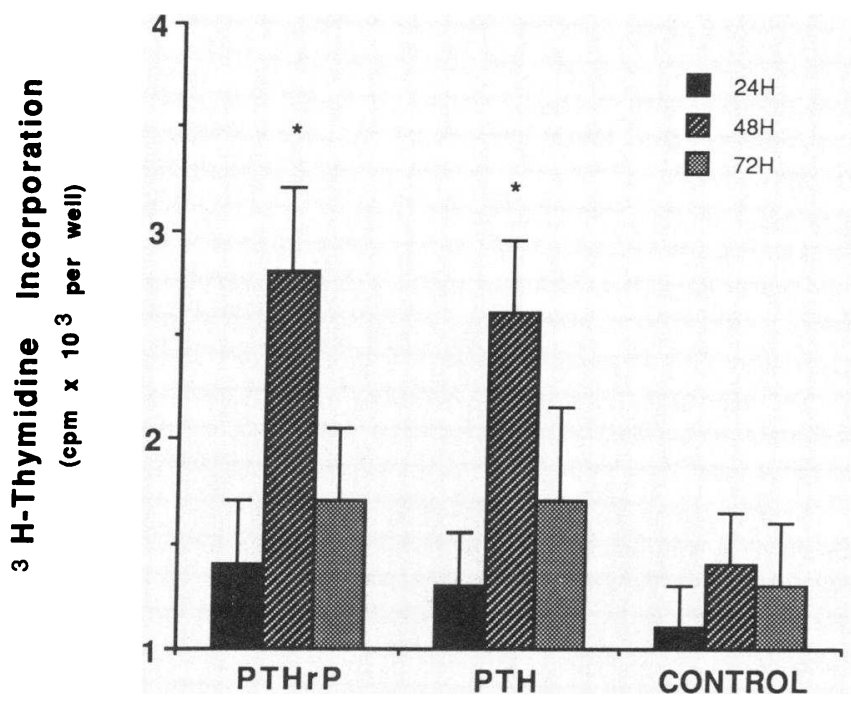

Figure 6. Induction of mesangial cell proliferation by PTHrP and PTH. $\left[{ }^{3} \mathrm{H}\right]$ Thymidine incorporation in cultured mesangial cells was measured after addition of $7 \times 10^{-9} \mathrm{M}$ PTHrP (1-36) or bPTH (1$34)$. Control wells received vehicle only. Cells were harvested at 24 , 48 , or $72 \mathrm{~h}$ after addition of peptide. $n=9$ for each time point. ${ }^{*} P$ $<0.01$. Direct cell counting of mesangial cell number at each time point resulted in the following values for the ratio of cell number in treated wells as compared with the initial time point at 24,48 , and $72 \mathrm{~h}$, respectively (SD in parentheses): $P$ THrP, $1.50(0.35), 2.75$ (0.45), 1.90 (0.30); PTH, 1.35 (0.28), 2.47 (0.36), 1.65 (0.27); CONTROL, $1.20(0.20), 1.35(0.20), 1.20(0.25)$. PTHrP and PTH values at $48 \mathrm{~h}$ were significant at $P<0.01$.

mals $(28,29)$. These growth factors are synthesized primarily by renal tubular cells $(26,27)$, although glomerular cells are now known to contribute to the repair process as well (26). In addition to increases in mRNA levels and growth effects of these cytokines, rapid increases in the levels of early response gene mRNAs (c-fos, Egr-1 and c-myc) occur after acute renal injury, presumably intended to stimulate the transcription of other factors involved in repair $(26,27)$.

PTHrP has been shown to have growth factor-like effects $(10-12,30,31)$, to act as an early response gene in some tissues $(13,14)$, and to be present in fetal kidney $(6-8)$, suggesting that PTHrP may play a role in the recovery from renal ischemia and acute tubular necrosis. We therefore studied the role of PTHrP in the adult kidney after an acute ischemic insult. The mRNA levels of most proteins and peptide hormones decrease in the rat kidney after ischemia. This is believed to be due to the generalized reduction in gene transcription rates in ischemic and recovering kidney (32), as well as to enhanced mRNA degradation. This generalized reduction in steady-state mRNA levels in the kidney was mirrored in this study by the reduction in both actin and cyclophilin mRNAs after ischemia. In marked contrast, however, PTHrP mRNA increased twofold after ischemic injury, and increased in a time frame similar to other known renal growth factors (26). The specific increment in PTHrP mRNA at a time when most mRNA species are diminishing suggests that PTHrP may have a role in the renal regenerative process.

While PTHrP mRNA levels increased after ischemic injury, PTH receptor mRNA levels decreased within $2 \mathrm{~h}$ after reperfusion. Although some RNA degradation may have occurred at these time points, this decrease may also reflect a generalized reduction in the rate of gene transcription, as described above. Since PTHrP binds to the classical PTH receptor in the kidney (1-3), it is possible that the increase in PTHrP synthesis in ischemic kidney results in a downregulation of the PTH receptor. This relationship between PTHrP and PTH receptor was recently demonstrated indirectly in cultured rat aortic smooth muscle cells, in which the upregulation of PTHrP mRNA after angiotensin II exposure was associated with a decrease in PTH receptor mRNA levels (33). Whether this represents homologous or heterologous downregulation is uncertain at present. These changes in PTHrP and PTH receptor are also consistent with the peptide-to-ligand relationship of other growth factors important in the renal regenerative process, such as with EGF (27).

A potential role for PTHrP during the recovery phase was further explored using immunolocalization in ischemic kidney. In the tubule, under basal conditions, antibodies directed at both amino-terminal and midregion portions of PTHrP revealed the presence of PTHrP in a vesicular pattern in proximal and distal tubular sites. After $6 \mathrm{~h}$ of reperfusion, PTHrP staining increased in intensity and now appeared in a diffuse cytoplasmic pattern, suggesting an increase in PTHrP protein production in these nephron sites. By $24 \mathrm{~h}$ of reflow, the cytoplasmic staining intensity had increased further, but an additional apical distribution of PTHrP was present. Many studies have documented changes in cellular distribution of proteins after renal ischemic injury, including protein products of early response genes, heat shock proteins, and cytoskeletal proteins $(15,34-36)$. These changes are believed to relate to the location of cellular injury and to early attempts at cellular repair $(15,26)$. From this perspective, it is important to note that growth effects of PTHrP have been observed in cultured MDCK (i.e., canine distal tubular) cells and in renal carcinoma cells $(10,11)$, as they have been in many nonrenal tissues. The enhanced staining of PTHrP within the tubules at 6 and $24 \mathrm{~h}$ after injury, together with the documented growth factor-like effects of PTHrP, suggest that PTHrP could play a regulatory role in growth or differentiation during tubular regeneration. The apical localization at $24 \mathrm{~h}$ may additionally reflect the movement of PTHrP toward the most severely injured portion of the tubule in order to contribute to the repair process, or may represent packaging into lysosomes for eventual apical secretion after providing its physiological effect. It is interesting to note that these changes are a mirror image to those observed with heat shock protein-72, where the peptide is located apically at early time points after renal injury and then localizes to the basolateral membrane by $24 \mathrm{~h}$ into the repair process (15). Finally, PTHrP was also identified in normal (i.e., sham-operated) renal tubular cells, suggesting a role for the peptide in normal adult renal tubule function in the rat.

The most unexpected observation in this study was the dramatic PTHrP staining in the glomerulus. Both visceral and parietal epithelial cells showed prominent PTHrP staining, while mesangial cells were almost completely negative. This was substantiated by confocal microscopy. Receptors for PTH are known to be present on both mesangial and epithelial cells $(37,38)$, yet no clear functional role for PTH in the glomerulus has been found. This is similar to other "nonclassical" PTH target tissues, such as vascular smooth muscle, pancreatic is- 
lets, epidermal keratinocytes, and lymphocytes, where PTH receptors are known to be present and where PTHrP is expressed, yet no functional role for PTH has been established (1-3). Since PTH is not synthesized in the glomerulus, it is possible that PTHrP induces its local effects through these PTH/PTHrP receptors. We and others have suggested that these receptors may actually be a subtype of PTH receptor, with PTHrP as the intended primary ligand (1-3).

In this study, PTHrP was shown to be both present in the glomerulus and to have an effect within glomerular cells. Without in situ hybridization data using PTHrP probes, however, these findings do not exclude the possibility that circulating PTHrP is trapped or concentrated by these cells. These findings appear to extend the observations of others indicating that communication may exist between the different glomerular cell types (39), and suggests that PTHrP may have an autocrine or paracrine role in these cells. It is interesting to note that in most histochemical analyses of PTHrP in rat and human fetal kidney, glomerular staining decreases or completely disappears by late gestation, while tubular staining remains prominent (68 ). The prominent glomerular findings in this study may represent differences in antibody affinity, epitope recognition sites, or in fixation methods.

In conclusion, PTHrP mRNA is increased after acute renal ischemic injury. PTHrP is present in the glomerulus and in both proximal and distal tubular cells, and stimulates DNA synthesis in mesangial cells. PTHrP is believed to have critical functions involving growth and development, transepithelial calcium transport, and smooth muscle regulation in an everexpanding list of tissues. These functions are only beginning to be explored. This study provides the first evidence of a role for PTHrP in the normal glomerulus and in injured kidney. Future studies will need to be performed in order to define the precise physiological and pathophysiological functions of this peptide.

\section{Acknowledgments}

We thank Drs. William J. Burtis and Lee Matovcik, and Barbara Dreyer, Tom Ardito, and Terence Wu for their advice and technical assistance. We also thank Ms. Charleen Stewart for outstanding manuscript preparation.

This work was supported by the Department of Veterans Affairs (N. E. Soifer, M. B. Ganz, A. F. Stewart), by National Institutes of Health grants DK-44336, T32 DK-07276, P30 HD-27757 and 5PO1 DK-1743320, by the American Heart Association Clinician Scientist Award (S. K. Van Why), and by the Baxter Extramural Research Program.

\section{References}

1. Stewart, A. F., and A. E. Broadus. 1990. Parathyroid hormone-related protein: coming of age in the 1990s. J. Clin. Endocrinol. \& Metab. 71:1410-1414. 2. Nissenson, R. A., and B. P. Halloran. 1992. Parathyroid Hormone-related Protein: Normal Physiology and Its Role in Cancer. CRC Press, Inc., Boca Raton, FL. 202 pp.

3. Strewler, G. J., and R. A. Nissenson. 1990. Hypercalcemia in malignancy. West. J. Med. 153:635-640.

4. Rodda, C. P., I. W. Caple, and T. J. Martin. 1992. Role of PTHrP in fetal and neonatal physiology. In Parathyroid Hormone-related Protein: Normal Physiology and Its Role in Cancer. R. A. Nissenson and B. P. Halloran, editors. CRC Press, Inc., Boca Raton, FL. 169-196.
5. Karapalis, A. C., V. Tybulewicz, R. C. Mulligan, and H. M. Kronenberg. 1992. Disruption of PTHrP gene leads to a multitude of skeletal abnormalities and perinatal mortality. J. Bone Miner. Res. 7(Suppl.):S93. (Abstr.)

6. Burton, P. B. J., C. Moniz, P. Quirke, A. Malik, T. D. Bui, H. Juppner, G. V. Segre, and D. E. Knight. 1992. Parathyroid hormone-related peptide: expression in fetal and neonatal development. J. Pathol. 167:291-296.

7. Campos, R. V., S. L. Asa, and D. J. Drucker. 1991. Immunocytochemical localization of parathyroid hormone-like peptide in the rat fetus. Cancer Res. 51:6351-6357.

8. Moniz, C., P. B. J. Burton, A. N. Malik, M. Dixit, J. P. Banga, K. Nicolaides, P. Quirke, D. E. Knight, and A. M. McGregor. 1990. Parathyroid hormone-related peptide in normal human fetal development. J. Mol. Endocrinol. 5:259-266.

9. Kramer, S., F. H. Reynolds, Jr., M. Castillo, D. M. Valenzuela, M. Thorikay, and J. M. Sorvillo. 1991. Immunological identification and distribution of parathyroid hormone-like protein polypeptides in normal and malignant tissues. Endocrinology. 128:1927-1937.

10. deMiguel, F., R. Garcia-Canero, and P. Esbrit. 1991. Co-purification of calcium transport-stimulating and DNA synthesis-stimulating agents with parathormone-like activity isolated from the hypercalcemic strain of the Walker 256 tumor. Eur. J. Cancer. 27:1022-1026.

11. Burton, P. B. J., C. Moniz, and D. E. Knight. 1990. Parathyroid hormone related peptide can function as an autocrine growth factor in human renal cell carcinoma. Biochem. Biophys. Res. Commun. 167:1134-1138.

12. Centrella, M., E. Canalis, T. L. McCarthy, A. F. Stewart, J. J. Orloff, and K. L. Insogna. 1989. Regulation of DNA and collagen synthesis in fetal rat bone through changes in TGF- $\beta$ action by parathyroid hormone-related protein. Endocrinology. 125:199-208.

13. Allinson, E. T., and D. J. Drucker. 1992. Parathyroid hormone-like peptide shares features with members of the early response gene family: rapid induction by serum, growth factors, and cycloheximide. Cancer Res. 52:3103-3109.

14. Thiede, M. A., S. C. Harm, D. M. Hasson, and R. M. Gardner. 1991. In vivo regulation of parathyroid hormone-related peptide messenger ribonucleic acid in the rat uterus by 17 $\beta$-estradiol. Endocrinology. 128:2317-2323.

15. Van Why, S. K., F. Hildebrandt, T. Ardito, A. S. Mann, N. J. Siegel, and M. Kashgarian. 1992. Induction and intracellular localization of HSP-72 after renal ischemia. Am. J. Physiol. 263:F769-775.

16. Chirgwin, J., A. Przybyla, R. MacDonald, and W. Rutter. 1979. Isolation of biologically active ribonucleic acid from sources enriched in ribonuclease. Biochemistry. 18:5294-5299.

17. Chomczynski, P., and N. Sacchi. 1987. Single step method of RNA isolation by acid guanidinium thiocyanate-phenol-chloroform extraction. Anal. Biochem. 162:156-159.

18. Juppner, H., A-B. Abou-Samra, M. Freeman, X-F. Kong, E. Scipani, J. Richards, L. F. Kolakowski, J. Hock, J. T. Potts, H. Kronenberg, and G. V. Segre. 1991. A G-protein linked receptor for parathyroid hormone and parathyroid hormone related peptide. Science (Wash. DC). 254:1024-1026.

19. Barbu, V., and F. Dautry. 1989. Northern blot normalization with a $28 \mathrm{~S}$ rRNA oligonucleotide probe. Nucleic Acids Res. 17:7115. (Abstr.)

20. Thiede, M., A. Daifotis, E. Weir, M. Brines, W. Burtis, K. Ikeda, B Dreyer, R. Garfield, and A. Broadus. 1990. Intrauterine occupancy controls expression of the parathyroid hormone-related peptide gene in pre-term rat myometrium. Proc. Natl. Acad. Sci. USA. 87:6969-6973.

21. Burtis, W. J., T. G. Brady, J. J. Orloff, J. B. Ersbak, R. P. Warrell, B. R. Olson, T. L. Wu, M. E. Mitnick, A. E. Broadus, and A. F. Stewart. 1990. Immunochemical characterization of circulating parathyroid hormone-related protein in patients with humoral hypercalcemia of cancer. N. Engl. J. Med. 322:1 106-1112.

22. Soifer, N. E., K. E. Dee, K. L. Insogna, W. J. Burtis, L. M. Matovcik, T. L. Wu, L. M. Milstone, A. E. Broadus, W. M. Philbrick, and A. F. Stewart. 1992. Parathyroid hormone-related protein: evidence for secretion of a novel mid-region fragment by three different cell types. J. Biol. Chem. 267:18236-18243.

23. Lovett, D. H., R. B. Sterzel, M. Kashgarian, and J. L. Ryan. 1983. Neutral proteinase activity produced in vitro by cells of the glomerular mesangium. Kidney Int. 23:342-349.

24. Striker, G. E., M. A. Lange, K. MacKay, K. Bernstein, and L. J. Striker. 1987. Glomerular cells in vitro. Adv. Nephrol. 16:169-186.

25. Ganz, M. B., M. C. Perfetto, and W. F. Boron. 1990. Effects of mitogens and other agents on rat mesangial cell proliferation, $\mathrm{pH}$, and $\mathrm{Ca}^{2+} . \mathrm{Am}$. J. Physiol. 259:F269-F278.

26. Toback, F. G. 1992. Regeneration after acute tubular necrosis. Kidney Int. 41:226-246.

27. Safirstein, R., P. M. Price, S. J. Saggi, and R. C. Harris. 1990. Changes in gene expression after temporary renal ischemia. Kidney Int. 37:1515-1521.

28. Humes, H. D., D. A. Cielinski, T. M. Coimbra, J. M. Messana, and C. Galvao. 1989. Epidermal growth factor enhances renal tubular cell regeneration and repair and accelerates the recovery of renal function in postischemic acute renal failure. J. Clin. Invest. 84:1757-1761. 
29. Miller, S. B., D. R. Martin, J. Kissane, and M. R. Hammerman. 1992. IGF-I accelerates recovery from ischemic acute tubular necrosis in the rat. J. Am. Soc. Nephrol. 3:710. (Abstr.)

30. Insogna, K. L., A. F. Stewart, C. A. Morris, L. M. Hough, L. M. Milstone, and M. Centrella. 1989. Native and synthetic analogue of the malignancy-associated parathyroid hormone-like protein have in vivo transforming growth factor-like properties. J. Clin. Invest. 83:1057-1060.

31. McCauley, L. K., T. J. Rosol, J. I. Merryman, and C. C. Capen. 1992. PTHrP binding to HTLV-1-infected lymphocytes. Endocrinology. 130:300-306.

32. Van Why, S. K., A. Mann, G. Thulin, N. J. Siegel, and M. Kashgarian 1992. Molecular regulation of $\mathrm{Na}, \mathrm{K}-\mathrm{ATPase}$ expression after renal ischemia. $J$ Am. Soc. Nephrol. 3:716. (Abstr.)

33. Pirola, C. J., H-M. Wang, A. Kamyar, S. Wu, H. Enomoto, B. Sharifi, J. S. Forrester, T. L. Clemens, and J. A. Fagin. 1993. Angiotensin II regulates parathyroid hormone-related protein expression in cultured rat aortic smooth muscle cells through transcriptional and post-transcriptional mechanisms. J. Biol. Chem. 286:1987-1994.

34. Kashgarian, M., S. K. Van Why, F. Hildebrandt, A. S. Mann, K. M. Gaudio, and N. J. Siegel. 1991. Regulation of expression and polar distribution of
$\mathrm{Na}, \mathrm{K}$-ATPase in renal epithelium during recovery from ischemic injury. In The Sodium Pump: Recent Developments. P. Kaplan and P. Deween, editors. Rockefeller University Press, New York. 573-577.

35. Kellerman, P. S., R. A. F. Clark, C. A. Hoilien, S. L. Linas, and B. A. Molitoris. 1990. Role of microfilaments in maintenance of proximal tubule structural and functional integrity. Am. J. Physiol. 259:F279-285.

36. Molitoris, B. A., C. A. Hoilien, R. Dahl, D. J. Ahnen, P. D. Wilson, and J. Kim. 1988. Characterization of ischemia-induced loss of epithelial polarity. $J$. Membr. Biol. 106:233-242.

37. Sraer, J., J. D. Sraer, D. Chansel, H. Jueppner, R. D. Hesch, and R. Ardaillou. 1978. Evidence for glomerular receptors for parathyroid hormone. Am. J. Physiol. 235:F96-103.

38. Rouleau, M. F., H. Warshawsky, and D. Goltzman. 1986. Parathyroid hormone binding in vivo to renal, hepatic, and skeletal tissues of the rat using a radioautographic approach. Endocrinology. 118:919-931.

39. Alpers, C. E., R. A. Seifert, K. L. Hudkins, R. J. Johnson, and D. F. Bowen-Pope. 1993. PDGF-receptor localizes to mesangial, parietal epithelial, and interstitial cells in human and primate kidneys. Kidney Int. 43:286-294. 